\title{
Evaluation of Soil Acidity in Agricultural Soils of Smallholder Farmers in South Western Ethiopia
}

\author{
Abdenna Deressa \\ Department of Soil Resource and Watershed Management, College of Agriculture and Natural Resource, \\ Wollega University, Post Box No: 395, Nekemte, Ethiopia
}

\begin{abstract}
The purpose of this study was to investigate the status of soil acidity in agricultural soils in West Wollega, East Wollega and West Showa zones of South Western Ethiopia. A total of 478 soil samples were collected in 2006, 2011 and 2012 G.C from 0-20cm depth. Thirteen representative districts from West Wollega, East Wollega and West Showa zones were selected purposively. Samples were collected from farmers' crop fields and analyzed at Nekemte Soil Research Center Laboratory for $\mathrm{pH}$ and exchangeable cations. Acid saturation percentages were derived by dividing exchangeable aluminum to sum of bases multiplied by 100 . Data were analyzed by SAS software. Mean soil pH of different districts in West Wollega, East Wollega and West Showa zones ranged from 4.91-5.29, 4.87-5.30, and 5.25-5.50, respectively. Mean exchangeable acidity in different districts in West Wollega, East Wollega and West Showa zones ranged from 1.89-3.84, 1.61-4.76, and $0.18-0.57 \mathrm{cmol}(+) / \mathrm{kg}$, respectively. Mean exchangeable aluminum of different districts in West Wollega, East Wollega and West Showa zones ranged from 1.63-3.53, 1.62-4.71, and $0.05-0.32 \mathrm{cmol}(+) / \mathrm{kg}$, respectively. Exchangeable acid saturation in different districts in West Wollega, East Wollega and West Showa zones ranged from 50-76, 16-43, and 1-6\%, respectively. Mean soil $\mathrm{pH}$ of study zones are rated as very strongly to strongly acidic and degree of acidity varies across districts. Moving from West Wollega zone to West Showa zone the extent of soil acidity and exchangeable acidity decreases. The soils of West Wollega and East Wollega zones have very high exchangeable aluminum and acid saturation percentages. Under such extreme acidity, major crops such as maize and sorghum in West Wollega and East Wollega zone may grow under suboptimal soil conditions. Thus, soil fertility research should geared towards ameliorating acidic soils with liming materials and developing crop varieties tolerant to soil acidity and Al toxicity.
\end{abstract}

\author{
Article Information \\ Article History: \\ Received : 03-04-2013 \\ Revised : 22-05-2013 \\ Accepted : 30-05-2013
}

\section{Keywords:}

Acid saturation

Exchangeable Acidity

Aluminum

$\mathrm{PH}$

Wollega Zones

${ }^{*}$ Corresponding Author:

Abdenna Deressa

E-mail:

dabdenna@yahoo.com

\section{INTRODUCTION}

Soil $\mathrm{pH}$ is a measure of the negative logarithm of the hydrogen ion activity in the soil solution. It is used as an indicator of the degree of acidity or alkalinity in soil. Based on $\mathrm{pH}$ scale, soil can be acidic, neutral or alkaline. Soil acidity is a term used to describe soils with a $\mathrm{pH}$ value less than 7.0 (Robarge, 2008). The $\mathrm{pH}$ is the master variable controlling ion exchange, dissolution, precipitation, oxidation reduction-adsorption and complexation (Murray, 1994). The combined interaction of these processes influence amount and speciation of nutrient ions in the soil solution and thus their availability for plant growth (Robarge, 2008). Acid soils are phyto-toxic due to nutritional disorders, deficiencies, unavailability of essential nutrients such as calcium, magnesium, molybdenum, and phosphorus, and toxicity of aluminum, manganese, and hydrogen activity (Ritchie, 1998; Hede et al., 2001). The dominance of aluminum on the ion exchange complex in acid soils directly affects plant growth particularly agronomic crops (Bloom, 2000; Hede et al., 2001). Aluminum toxicity is a particular management problem and occurs mainly when $\mathrm{pH}$ in water is less than 5.0 (Robarge, 2008; Menzies, 2003). High rain fall, decomposition of organic matter, acidic parent materials, removal of basic cations, application of ammonium fertilizers and intense weathering are the main cause of soil acidity (Hede et al., 2001; Sumner and Noble, 2003). 


\section{Abdenn Deressa}

Teff, barely, wheat, maize, sorghum and finger millet are the major cereal crops grown in East and Wollega zones of Ethiopia (Statistical Bulletin, 2012). Production of these major cereal crops in these regions have increased in the last decade. Much of the increase in cereal crops production in these zones in past decade is due to increase in area cultivated. However, yield per unit area remained stagnant (Alemayehu et al., 2011). Numerous constraints to yield and productivity growth have been attributed to low levels of input use such as fertilizers, pesticide, improved seeds and low levels of irrigation, soil degradation, soil erosion, inadequate agricultural research and extension, and constraints in market development (Alemayehu et al., 2011; IFPRI, 2010). Smallholder farmers in different districts in East and West Wollega zones have reported yield stagnation and even yield decline of cereal and pulse crops and lack of response to application of urea and diammonium phosphate fertilizers. The lack of response to fertilizers and yield decline may due to deficiencies of essential such as phosphorus, calcium, magnesium and toxicity of acidic cations such as aluminum, iron and manganese in the agricultural soil systems. As the result this research was carried out to thoroughly investigate the status of surface soil acidity in West Wollega, East Wollega and West Showa zones of South Western Ethiopia.

\section{MATERIALS AND METHODS}

\section{Description of Study Location}

The study was conducted in three zones of Western Ethiopia. These are West Wollega, East Wollega and West Showa zones. From West Wollega zone, five districts namely Mana Sibu, Nejo, Jarso, Boji and Gimbi districts were selected. From East Wollega zone, Guto Gida, Leqa Dullacha, Gida Ayana, Kiremu, Sasiga and Diga districts were selected. From West Showa zone, Bako Tibe and Chaliya districts were selected. The selected districts are representative of each zone and were selected purposively. The ten years (1996-2007) climatic data from Nekemte Meteorological Station recorded an average annual rainfall $1780 \mathrm{~mm}$ which is characterized by mono modal rainfall pattern and its annual mean minimum and maximum monthly temperatures lies between 13.75 and $27.65{ }^{\circ} \mathrm{C}$ (Achalu et al., 2012). The topography of the study area is undulating. According to FAO (1990) soil classification system, the soil class of the study zones is dystric Nitisols. The livelihoods of the rural communities of the study districts depend mainly on crop production, animal husbandry and mixed farming systems. The major crops of the areas are coffee, maize, sorghum, teff,
Sci. Technol. Arts Res. J., April-June 2013, 2(2): 01-06

wheat, barley, sesame, finger millet, haricot bean, faba bean, field pea and lima bean.

\section{Soil Sampling and Analysis}

A total of one hundred twenty five soil samples were collected from Boji, Jarso, Nejo, Mana Sibu and Gimbi, Diga, Leqa Dulacha, Guto Gida, Bako Tibe and Chaliya districts in 2005 and 2006. In 2011 and 2012, additional three hundred fifty three soil samples were collected from Kiremu, Sasiga, Gida Ayana, Guto Gida and Diga districts. The samples were collected from $0-20 \mathrm{~cm}$ depth by auger from farmers' fields. Composite samples were collected from uniform farmers' field, standard sampling techniques and sample preparation procedures were followed. During sampling the farmers were asked to mention the type of crops they grow in the parcel of farmland in next cropping season. The samples were transported to Nekemte soil research center for laboratory analysis. Soil $\mathrm{pH}$ was determined in soil to water ratio of $1: 2.5(\mathrm{w} / \mathrm{v})$. Exchangeable bases ( $\mathrm{Ca}, \mathrm{Mg}, \mathrm{Na}$, and $\mathrm{K}$ ) were extracted with $1 \mathrm{M}$ ammonium acetate at $\mathrm{pH} 7 . \mathrm{Ca}$ and $\mathrm{Mg}$ were analyzed by titrations using EDTA method. Exchangeable $\mathrm{K}$ and $\mathrm{Na}$ were measured by flame photometer. However, exchangeable bases (calcium, magnesium, sodium, and potassium) are not reported in this paper. Exchangeable acidity (Al $+\mathrm{H}$ ) was determined by saturating the samples with $1 \mathrm{M} \mathrm{KCl}$ solution and titrated with sodium hydroxide as described by McLean (1965). Acid saturation percentages were determined by dividing exchangeable acidity to sum of exchangeable cations multiplied by 100 . Similarly, aluminum saturation percentages were determined by dividing exchangeable aluminum to total exchangeable cations multiplied by 100 . Descriptive statistics was carried out using SAS software version 9.01 (SAS, 2004).

\section{RESULTS AND DISCUSSIONS}

$\mathrm{PH}$ of soil samples from 13 districts in West Wollega, East Wollega and West Showa zones of south western and central Ethiopia are presented in Table 1. The distributions of soil pH in these districts are also illustrated in Figure 1. The mean soil pH of Boji, Gimbi, Jarso, Mana Sibu and Nejo districts of West Wollega zone are 4.91, 5.05, 4.93, 5.29, and 5.00 , respectively. The mean soil pH of Diga, Gida Ayana, Guto Gida, Kiremu, Leqa Dulacha and Sasiga districts of East Wollega zone are 5.30, 5.01, $4.87,5.06,4.88$, and 4.90 , respectively. The mean soil $\mathrm{pH}$ of Bako Tibe and Chaliya districts of West Showa zone are 5.5 and 5.25 , respectively.

According to Robarge (2008), Hazelton and Murphy (2007), Donald (2003) and Benton (2003) the mean soil pH of Gimbi, Mana Sibu, Diga, Gida 
Table 1: Descriptive statistics of soil $\mathrm{pH}\left(\mathrm{H}_{2} \mathrm{O}\right)$ values collected from cropland in 13 districts of West Wollega, East Wollega and West Shoa Zones of South Western Ethiopia.

\begin{tabular}{lllllll}
\hline Zones & Districts & $\mathbf{N}^{*}$ & Mean & Std Dev & Minimum & Maximum \\
\hline \multirow{5}{*}{ West Wollega } & Boji & 15 & 4.91 & 0.26 & 4.57 & 5.56 \\
& Gimbi & 15 & 5.05 & 0.34 & 4.50 & 5.57 \\
& Jarso & 15 & 4.93 & 0.35 & 4.33 & 5.50 \\
& Mana Sibu & 14 & 5.29 & 0.15 & 4.90 & 5.40 \\
& Nejo & 15 & 5.00 & 0.43 & 4.10 & 5.80 \\
\hline \multirow{5}{*}{ East Wollega } & Diga & 70 & 5.30 & 0.33 & 4.54 & 6.41 \\
& Gida Ayana & 57 & 5.01 & 0.22 & 4.58 & 5.44 \\
& Guto Gida & 90 & 4.87 & 0.30 & 4.23 & 6.10 \\
& Kiremu & 122 & 5.06 & 0.24 & 4.48 & 5.75 \\
& Leqa Dulacha & 10 & 4.88 & 0.20 & 4.60 & 5.23 \\
& Sasiga & 77 & 4.90 & 0.29 & 4.28 & 5.64 \\
\hline \multirow{2}{*}{ West Showa } & Bako Tibe & 10 & 5.50 & 0.18 & 5.22 & 5.85 \\
& Chaliya & 10 & 5.25 & 0.31 & 4.87 & 5.89 \\
\hline
\end{tabular}

${ }^{*}$ Total Soil Samples analyzed
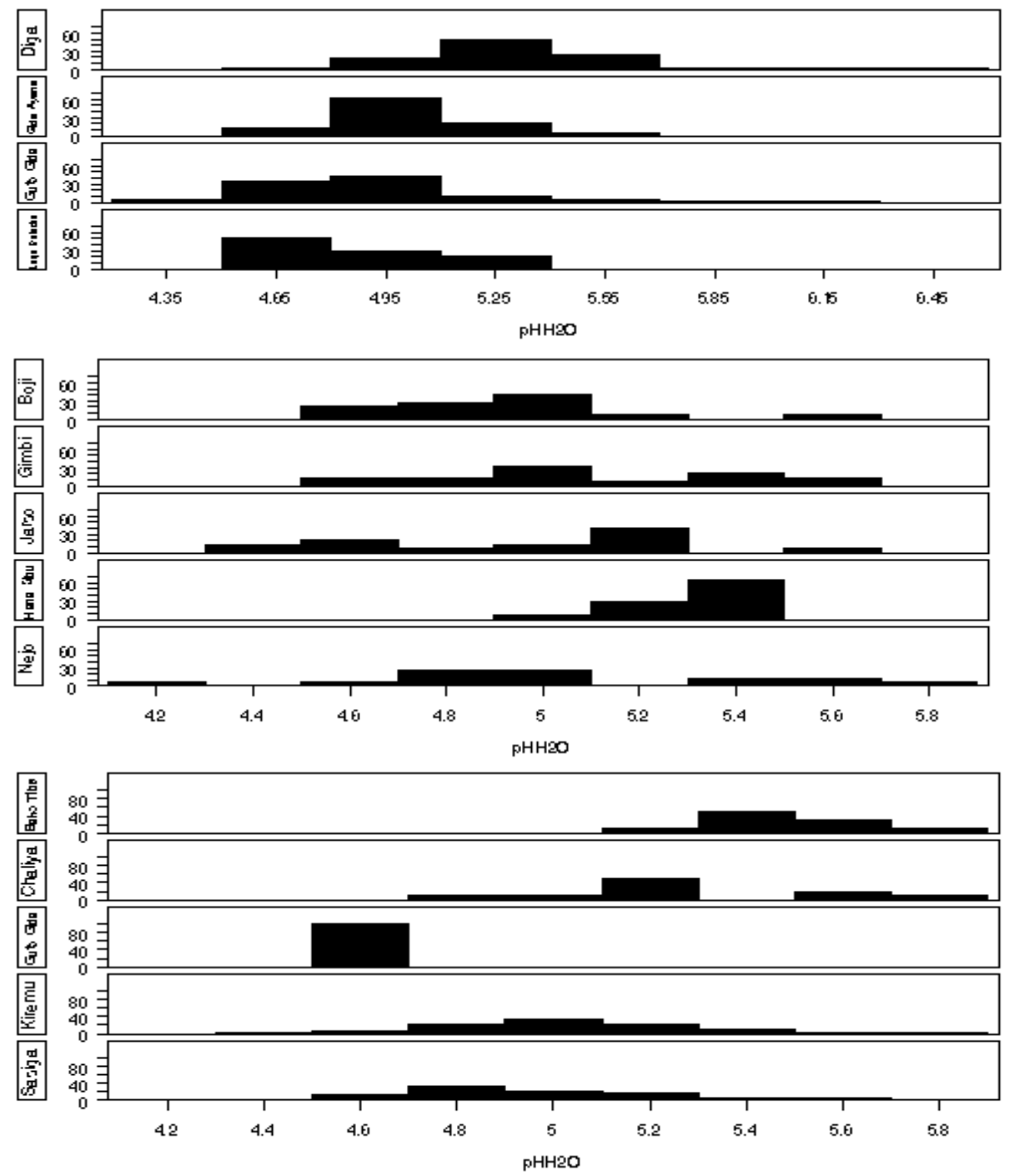

Figure 1: Frequency distribution of soil pH in soils collected from croplands in 13 districts of East Wollega zone, West Wollega and West Showa in southwestern Ethiopia. 


\section{Abdenn Deressa}

Ayana, Kiremu, Bako Tibe and Chaliya districts fall category of strongly acidic soils while mean soil $\mathrm{pH}$ of Boji, Nejo, Guto Gida, Leqa Dulacha and Sasisga districts fall in the category of very strongly acidic soils. These results are in agreement with reports of Wakene et al. (2007) who reported that soil $\mathrm{pH}$ in cropland of Bako Research Center in Gobu Sayo district is categorized as strongly acidic. Abdenna et al. (2007) and Fite et al. (2007) also reported similar soil acidity status which is categorized as very strongly to strongly acidic in croplands of Gimbi, Mana Sibu, Bako Tibe and Chaliya districts in West Wollega, East Wollega and West Showa zones of south western Ethiopia.

Soil $\mathrm{pH}$ is probably the most important master chemical soil parameter and it reflects the overall chemical status of the soil and influences a whole range of chemical and biological processes occurring in the soils (Robarge, 2008; Bloom, 2000). For example, most plants and soil organisms prefer pH range between 6.0 and 7.5 (Hall, 2008; Hazelton and Murphy, 2007). The results obtained from different districts of West Wollega, East Wollega and West Showa zones showed that the $\mathrm{pH}$ of these soils are out of this normal $\mathrm{pH}$ range. Under
Sci. Technol. Arts Res. J., April-June 2013, 2(2): 01-06

such low $\mathrm{pH}$ the availability of essential nutrients are critically affected. Toxicity of aluminum to plants greatly affects root and shoot growth as well as nutrients and water absorption. Moreover, the activities of microorganisms which play pivotal roles in nutrient cycling in agro ecosystems are affected.

The mean soil exchangeable acidity of Boji, Gimbi, Jarso, Mana Sibu and Nejo districts from West Wollega zone $3.84-1.98 \mathrm{cmol}(+) / \mathrm{kg}$. The mean exchangeable acidity of Diga, Gida Ayana, Guto Gida, Kiremu, Leqa Dulacha and Sasiga districs ranged from $1.61-4.76 \mathrm{cmol}(+) / \mathrm{kg}$ and exchangeable acidity from Bako Tibe and Chaliya districts are 0.18 and $0.57 \mathrm{cmol}(+) / \mathrm{kg}$, respectively. There is considerable variation among samples in exchangeable acidity within and among districts and among zones. The distributions of soil exchangeable acidity in districts and zones are illustrated in Table 2. This variation in exchangeable acidity may be due variation in soil $\mathrm{pH}$, soil organic matter, soil texture and cropping history. According to Hazelton and Murphy (2007) and Moore (2001) the mean exchangeable acidity in all study districts except Bako Tibe and Chaliya districts are categorized or rated as very high.

Table 2: Descriptive statistics of exchangeable acidity, $\mathrm{cmol}(+) / \mathrm{kg}$, in soils collected from cropland in 13 districts of West Wollega, East Wollega and West Shoa Zones of South Western Ethiopia.

\begin{tabular}{cllllll}
\hline Zones & Districts & $\mathbf{N}^{*}$ & Mean & Std Dev & Minimum & Maximum \\
\hline \multirow{4}{*}{ West Wollega } & Boji & 15 & 3.84 & 1.88 & 0.87 & 6.48 \\
& Gimbi & 15 & 1.89 & 1.55 & 0.14 & 6.05 \\
& Jarso & 15 & 3.38 & 2.11 & 0.58 & 7.56 \\
& Mana Sibu & 14 & 2.17 & 1.48 & 1.08 & 6.41 \\
& Nejo & 15 & 2.32 & 1.71 & 0.07 & 4.97 \\
\hline \multirow{5}{*}{ East Wollega } & Diga & 70 & 3.59 & 1.25 & 1.10 & 6.30 \\
& Gida Ayana & 57 & 4.55 & 1.75 & 1.00 & 7.70 \\
& Guto Gida & 90 & 4.76 & 1.55 & 1.80 & 8.90 \\
& Kiremu & 122 & 3.37 & 1.79 & 0.10 & 8.50 \\
& Leqa Dulacha & 10 & 1.61 & 0.96 & 0.22 & 3.02 \\
& Sasiga & 77 & 3.28 & 2.73 & 0.10 & 10.90 \\
\hline \multirow{2}{*}{ West Showa } & Bako Tibe & 10 & 0.18 & 0.09 & 0.07 & 0.36 \\
& Chaliya & 10 & 0.57 & 0.42 & 0.07 & 1.44 \\
\hline
\end{tabular}

The mean exchangeable aluminum in five districts of West Wollega zone, three districts of East Wollega zone and two districts of West Showa zone are presented in Table 3. Soils from West and East Wollega zones have very high exchangeable acidity while soils from West Showa have low to marginal exchangeable aluminum. Districts which have higher soil $\mathrm{pH}$ value have lower exchangeable acidity and the vice versa. This finding is in agreement with Lindsay (1996) and Moore (2001) who reported that solubility of Al containing minerals increase as soil $\mathrm{pH}$ falls below 5.5 and suggested that probability of Al toxicity to plants become higher. Mean exchangeable acid saturation percentage of soils from West Wollega Soils ranged from $50-76 \%$ and mean exchangeable acid saturation percentage ranged from $16-43 \%$ while mean soil exchangeable acid saturation percentage from West Showa zone ranged from 1-6\% (Table 4). According to Fageria and Baligar (2003) maize and sorghum show toxicity symptom of acidity at $20 \%$ acid saturation. This indicates that maize and sorghum which are major cereal crops grown in West and East Wollega zones are suffering from toxicity of exchangeable acidity. However, exchangeable acid saturation percentage in soils from Bako Tibe and Chaliya districts of West Showa are low and toxicity of exchangeable acidity to 
Abdenn Deressa

sorghum and maize crops are less likely to happen. Moving from West Wollega to West Showa zone,
Sci. Technol. Arts Res. J., April-June 2013, 2(2): 01-06

exchangeable acid saturation percentages and the risk of toxicity of acidity decrease.

Table 3: Descriptive statistics of exchangeable aluminum, $\mathrm{cmol}(+) / \mathrm{kg}$, in soils collected from cropland in 13 districts of West Wollega, East Wollega and West Showa Zones of South Western Ethiopia.

\begin{tabular}{clccccc}
\hline Zones & Districts & $\mathbf{N}^{*}$ & Mean & Std Dev & Minimum & Maximum \\
\hline \multirow{5}{*}{ West Wollega } & Boji & 15 & 3.52 & 1.72 & 0.65 & 5.76 \\
& Gimbi & 15 & 1.70 & 1.35 & 0.14 & 5.04 \\
& Jarso & 15 & 2.82 & 1.98 & 0.36 & 6.77 \\
& Mana Sibu & 14 & 1.63 & 1.19 & 0.63 & 4.61 \\
& Nejo & 15 & 2.00 & 1.48 & 0.07 & 4.32 \\
\hline \multirow{3}{*}{ East Wollega } & Diga & 15 & 2.88 & 1.38 & 1.15 & 5.04 \\
& Guto Gida & 15 & 4.71 & 1.59 & 1.80 & 6.12 \\
& Leqa Dulacha & 10 & 1.62 & 0.88 & 0.22 & 2.88 \\
\hline \multirow{2}{*}{ West Showa } & Bako Tibe & 10 & 0.02 & 0.05 & 0.00 & 0.14 \\
& Chaliya & 10 & 0.32 & 0.38 & 0.00 & 1.15 \\
\hline
\end{tabular}

${ }^{*}$ Total Soil Samples analyzed

Table 4: Descriptive statistics of exchangeable acid saturation percentages of soils collected from cropland in 13 districts of West Wollega, East Wollega and West Showa Zones of South Western Ethiopia.

\begin{tabular}{clccccc}
\hline Zones & Districts & $\mathbf{N}^{*}$ & Mean & Std Dev & Minimum & Maximum \\
\hline \multirow{5}{*}{ West Wollega } & Boji & 15 & 76 & 22 & 34 & 97 \\
& Gimbi & 15 & 50 & 35 & 3 & 94 \\
& Jarso & 15 & 57 & 26 & 20 & 96 \\
& Mana Sibu & 14 & 46 & 21 & 24 & 90 \\
& Nejo & 15 & 63 & 32 & 3 & 91 \\
\hline \multirow{5}{*}{ East Wollega } & Diga & 70 & 31 & 12 & 6 & 55 \\
& Gida Ayana & 57 & 43 & 17 & 9 & 74 \\
& Guto Gida & 90 & 40 & 15 & 10 & 82 \\
& Kiremu & 122 & 31 & 17 & 1 & 70 \\
& Leqa Dulacha & 10 & 16 & 10 & 2 & 33 \\
& Sasiga & 77 & 34 & 26 & 1 & 80 \\
\hline \multirow{2}{*}{ West Showa } & Bako Tibe & 10 & 1 & 1 & 0 & 3 \\
& Chaliya & 10 & 6 & 6 & 0 & 20 \\
\hline
\end{tabular}

${ }^{*}$ Total Soil Samples analyzed

\section{CONCLUSIONS}

Soils of West Wollega, East Wollega and West Showa zones of south western Ethiopia are acidic and the degree of acidity varies across districts. Most of the soils are very strongly to strongly acidic while a few soils are moderately to slightly acidic. Moving from West Wollega zone to West Showa zone the extent of soil acidity and exchangeable acidity decreases. The soils of West Wollega and East Wollega zones have very high exchangeable aluminum and acid saturation percentages. Most of soils of East and Wollega zones are not suitable for moderate to sensitive crops to soil acidity. Under these extreme acidic soil conditions, the major crops of East Wollega zone such as maize and sorghum grow under suboptimal soil conditions. In order to increase production and productivity of these soils, soil fertility research should geared towards ameliorating acidic soils with organic and inorganic liming materials to increase $\mathrm{pH}$ and avoid aluminum toxicity that has paramount contribution to achieve sustainable food security in the region. Moreover, soil fertility research should focus on improving crop genetics for tolerance to soil acidity and Al toxicity which can be complementary to or independent of soil liming.

\section{REFERENCES}

Abdenna Deressa., Wakene Negassa., Chewaka and Tilahun Geleto. (2007). Inventory of soil acidity status in crop lands of central and western Ethiopia. In: Utilization of diversity in land use systems Sustainable and organic approaches to meet Human needs, Witzenhausen, 9-11.

Achalu Chimdi., Heluf Gebrekidan., Kibebew Kibret. and Abi Tadesse. (2012). Status of selected physicochemical properties of soils under different land use systems of Western Oromia, Ethiopia. Journal of Biodiversity and Environmental Sciences 2(3): $57-71$.

Alemayehu Seyoum Taffesse., Paul Dorosh and Sinafikeh Asrat. (2011). Crop Production in Ethiopia: Regional Patterns and Trends. Development Strategy and 


\section{Abdenn Deressa}

Governance Division, International Food Policy Research, Institute, Ethiopia Strategy Support Program II, Ethiopia.

Benton J. Jones. (2003). Agronomic handbook: Management of crops, soils, and their fertility. CRC Press LLC, 2000 N.W. Corporate Blvd., Boca Raton, Florida 33431. Pp 482.

Bloom, P.R. (2000). Soil pH and pH buffering. In: Sumner, M.E. (eds). Handbook of Soil Science. Boca Raton, FL: CRC Press.

Donald L. Sparks. (2003). Environmental Soil Chemistry. Second Edition. University of Delaware, Academic Press, An imprint of Elsevier Science, Pp 367, http://www.academicpress.com.

Fageria Nand and Virupax C. Baligar. (2003). Fertility Management of Tropical Acid Soils for Sustainable Crop Production. In: Zdenko Rengel (eds.) Handbook of Soil Acidity. University of Western Australia, Perth, Western Australia, Australia.

FAO. (1990). Soil Map of the World: Revised legend FAO (Food and Agriculture Organization), Rome, Italy.

Fite Getaneh., Abdenna Deressa., Wakene Negassa Chewaka. (2007). Influence of Irrigation on Soil Chemical Properties. In: Utilization of diversity in land use systems: Sustainable and organic approaches to meet human needs. A paper presented on Tropentag 2007, October 9 -11, 2007, Witzenhausen, Germany.

Hall Roger Elliot. (2008). Soil essentials: Managing your farm's primary asset. Printed in Australia by BPA Print Group. Pp. 191

Hazelton Pam and Brian Murphy. (2007). Interpreting Soil Test Results. What Do All the Numbers Mean? Published by CSIRO Publisjing. Pp160.

Hede, A.R., Skovmand, B. and Lopez-Cesati, J. (2001). Acid Soils and Aluminum Toxicity. In: Reynolds, M.P., Ortiz-Monasterio, J.I and McNab, A (eds.). Application of Physiology in Wheat Breeding, Mexico, D.F.: CIMMYT.

IFPRI (International Food and Policy Research Institute). (2010). Fertilizer and Soil Fertility Potential in Ethiopia. Constraints and opportunities for enhancing the system.

Lindsay, W.L., Walthall, P.M. (1996). The solubility of aluminum in soils. In: Sposito, G. (eds). The Environmental Chemistry of Aluminum. Boca Raton, FL: CRC Press, Pp 333-361.

McLean, E.O. (1965). Aluminum. In: Black, C.A. (Ed.). Methods of Soil Analysis. Agronomy Series No. 9. Part II. pp. 978-998. American Society of Agronomy, Madison, Wisconsin, USA.

Menzies Neal W. (2003). Toxic Elements in Acid Soils: Chemistry and Measurement. In: Zdenko Rengel (ed.) Handbook of Soil Acidity. University of Western Australia, Perth, Western Australia, Australia.

Moore Geoff. (2001). Soil Guide: A Hand Book For Understanding and Managging Agricultural Soils. Compiled and Edited By Geoff Moore, Bulletin 4343.
Sci. Technol. Arts Res. J., April-June 2013, 2(2): 01-06

Murray B. McBride. (1994). Environmental Chemistry of Soils. Oxford University Press. New York. Pp 441.

Ridley, W.J., Slattery, K.R., Helyar, A., Cowling. (1990). The importance of the carbon cycle to acidification of a grazed annual pasture. Australian Journal of Experiments in Agriculture 30:529-537.

Ritchie, G.S.P., (1989). The chemical behavior of aluminum, hydrogen and manganese in acid soils. In Robson, A.D., ed., Soil Acidity and Plant Growth. Sydney: Academic Press, pp. 1-60.

Robarge Wayne P. (2008). Acidity. In: Encyclopedia of Soil Science, Encyclopedia Of Earth Sciences Series (Ed.: Ward Chesworth). Pp 860.

SAS Institute inc. (2004). SAS/STAT Guide: version 9.1, SAS Institute Inc, Cam, North Carolina.

Statistical Bulletin. (2012). The Federal Democratic Republic Of Ethiopia. Central Statistical Agency. Agricultural Sample Survey. 2011 / 2012 (2004 E.C.), (September - December 2011), Volume I, Report On Area And Production Of Major Crops (Private Peasant Holdings, Meher Season) Addis Ababa, May, 2012

Sumner Malcolm E. and Andrew D. Noble. (2003). Soil Acidification: The World Story. In: Zdenko Rengel (ed.) Handbook of Soil Acidity. University of Western Australia, Perth, Western Australia, Australia.

Wakene Negassa., Fite Getaneh., Abdenna Deressa, and Birhanu Dinsa. (2007). Integrated Use of Organic and Inorganic Fertilizers for Maize Production. In: "Utilization of diversity in land use systems: Sustainable and organic approaches to meet human needs". A paper presented on Tropentag 2007, October 9 - 11, 2007 Witzenhausen, Germany. 